Journal of Engineering Sciences, Assiut University, Vol. 41 No 1 pp. - January 2013

\title{
EFFECT OF OPENINGS ON THE STATICAL BEHAVIOUR OF REINFORCED HIGH STRENGTH CONCRETE L- BEAMS
}

\author{
DR. A. Y. ABOUELEZZ
}

Lec. , Civil Eng. Dep, Minia University, Minia, Egypt

E-mail:dr_alaa_abouelezz@yahoo.com

ENG. S.A. EL- BASSUONI

M.Sc. Student, Civil Eng. Dep, Minia University, Minia, Egypt

(Received January 19, 2012 Accepted June 23, 2012)

\section{ABSTRACT}

There is a growing trend in constructing high-rise buildings towards eliminating the extra space above false ceilings by passing service ducts through openings in the floor beams. Such an arrangement of building services leads to a significant reduction in the dead space, and results in a more compact and economical design. However, including openings in the web of a reinforced concrete beam induces high stress concentration at opening corners, reduces beam stiffness, and alters the simple beam behavior to a more complex one. Therefore, this work investigates the effect of openings on the statical behavior of high strength L- section reinforced concrete beams.

For this purpose, thirteen reinforced concrete beams of L- section, with web openings, were tested. The studied parameters were: opening position, concrete compressive strength, length of the opening, reinforcement around the opening, and shape of the opening (rectangular, square, and circle). Cracking and ultimate loads were recorded; deflections at the position of mid- span and at the center of the opening were measured. Pattern of cracks and modes of failure were observed

It was found that, decreasing the compressive strength of the used concrete, or the steel reinforcement around the opening, and increasing the opening length have a great effect on cracking and ultimate loads, pattern of cracks, and maximum induced deflections and strains, i.e., bearing capacity, and deformation capacity of such tested beams.

KEYWORDS: High strength concrete, H.S.C. L- section beam, web openings.

\section{1-INTRODUCTION}

Pipes and ducts are necessary to accommodate many important services like water supply, sewage, air- conditioning, and heating systems. When these ducts are provided under the beams and then covered by a suspended ceiling, a "dead space" is created in each floor, which is added to the overall height of the building, To save this dead space, there is a growing trend to pass these ducts through transverse openings in the beams, This will reduce the headroom, walls and partition surfaces, and overall load on the foundation. This process will transform the conventional 


\section{Dr. A. Y. ABOUELEZZ, ENG. S.A. EL- BASSUONI}

behavior of beams to a more complex one due to the sudden change in cross section and high stress concentration at the corners.

High strength concrete (H.S.C) has been utilized in large span bridges, skyscrapers, and high-rise buildings. This is because (H.S.C) offers many advantages over normalstrength concrete (N.S.C.) that has been produced for almost a century with a 28 - days compressive strength ranging from 20 to $40 \mathrm{Mpa}$. The (ACI 318-02) defines High Strength Concrete (H.S.C) as the concrete which has a 28 - days cylinder compressive strength (fc') above (55 Mpa). Using (H.S.C) reduces the cross-section of the structural elements in buildings. It has high modulus of elasticity, high durability, low permeability, and good resistance to impact and abrasion. Therefore, the present research mainly concentrates on the study of the structural behavior of H.S.C. Lsection beam having web openings

\section{2- REVIEW OF PREVIOUS WORK}

Most researches have investigated the characteristics of R.C. rectangular beams with openings, Meanwhile, the behavior of R.C.L section beams has been investigated in few researches, particularly those fabricated with H.S.C..

Abd El-Shafy, Z. E., 2007, studied the behavior of high- strength reinforced concrete Twenty $\mathrm{T}$ - beams with large rectangular web opening in negative moment region. His conclusions were increasing the main reinforcement ratio or horizontal reinforcement ratio around openings has a slight effect on the behavior of beams, The variation of the opening depth and length has great effect on maximum deflection ,strains, and ultimate loads.

Nassef, M. B., et. al. 1985 studied the behavior of reinforced concrete beams with openings located in the shear zones. The main variables in this work were the effect of opening shape, top flange width, and reinforcement details around the openings.

Mansur, M. A., 2004, studied the behavior of multiple openings and the way of the design posts. An inverted T-beam with multiple rectangular openings, separated by adequately reinforced posts. He concludes that $\mathrm{T}$ - beams, openings should, be positioned flush with the flange for ease in construction. In the case of rectangular, openings are commonly placed at mid- depth of the section. also- Openings should not be located closer than one- half the beam depth to the supports. Similarly, positioning of an opening closer than one-half the beam depth should be avoided. Also, the depth of openings should be limited to $50 \%$ of the overall beam depth.

Tan, K. H., et-al, 1996, carried out an experimental program on fifteen test specimens, each with loading conditions simulating either the negative or the positive moment regions of a reinforced concrete continuous $\mathrm{T}$-beams.

\section{EXPERIMENTAL WORK}

Thirteen reinforced concrete beams of L-section with depth of $25 \mathrm{~cm}$, width of 12 $\mathrm{cm}$, and flanges with thickness of $6 \mathrm{~cm}$, and width of $35 \mathrm{~cm}$. were tested under one point static load at mid span. They were simply supported $1.6 \mathrm{~m}$ apart. Complete details of all tested beams, and their reinforcement are mentioned in table (1), and shown in Figures (1 to 13 ). 
Control Beam designated (B1) does not contain any openings. It was tabulated in a separate group named

\section{-(Group A):}

The remaining beams with openings were divided into five as follows:

\section{- Group B:}

In this group, the effect of the opening position along the beam axis was studied. This group includes three beams (B2, B3, B4), all of them were made of a high- strength concrete with a compressive strength of $75 \mathrm{Mpa}$. The opening in each beam was $24 \mathrm{~cm}$ long, and $8 \mathrm{~cm}$ deep. Reinforcement around the opening was two bars of $10 \mathrm{~mm}$ diameter, in each side, around the horizontal and vertical directions. The opening of beam (B2) was located at the nearest possible place to the supports, which equals onehalf the beam depth.

\section{- Group C:}

Two compressive strength of $50 \mathrm{Mpa}$, and $90 \mathrm{Mpa}$ were used in this group, Beams (B5), and (B6)

\section{- Group D:}

In this group, the effect of the length of the rectangular opening was studied. Two beams were included in this group (B7), and (B8). The length of the opening of beam (B7) was $16 \mathrm{~cm} \quad\left(2 \mathrm{~d}_{\mathrm{o}}\right)$; while in beam (B8), the opening length was $32 \mathrm{~cm}\left(4 d_{o}\right)$, where $\left(d_{o}\right)$, is the depth of the opening.

\section{- Group E:}

The influence of using horizontal and vertical reinforcement around the opening was studied In this group,. Three R. C. beams (B9), (B10), and (B11), The opening in beam (B9) was not reinforced, meanwhile, beam (B10) was reinforced with two bars of $8 \mathrm{~mm}$ diameter around the opening. However, in beam (B11), two bars $12 \mathrm{~mm}$ diameter were fixed around the opening.

\section{- Group F:}

In this group, the effect of opening shape (square, or circle) was studied. In this group; (B12), and (B13). The area of the two chosen openings were kept the same. The opening in beam (B12) was a square shape with a side length of $13.9 \mathrm{~cm}$, while the opening in beam (B13) was circular with a diameter of 15.6 $\mathrm{cm}$. 
Table (1): Details of The Tested Beams

\begin{tabular}{|c|c|c|c|c|c|c|c|c|c|c|}
\hline GROUP & $\begin{array}{c}\text { BEA } \\
\text { M }\end{array}$ & $\begin{array}{l}\text { Lo } \\
(\mathrm{cm})\end{array}$ & $\begin{array}{l}\text { Do } \\
(\mathrm{cm})\end{array}$ & $\begin{array}{c}\mathrm{Lo} / \\
\text { do }\end{array}$ & $\begin{array}{c}\text { Ao } \\
(\mathrm{cm} 2)\end{array}$ & So & $\mu^{\prime}$ & $\begin{array}{c}\text { Fcu } \\
(\mathrm{Mpa} \\
)\end{array}$ & $\overline{A s}$ & Shape \\
\hline A & B1 & --- & --- & --- & --- & --- & --- & 75 & --- & --- \\
\hline \multirow[t]{3}{*}{ B } & B2 & \multirow{3}{*}{24} & \multirow{3}{*}{8} & \multirow{3}{*}{3} & \multirow{3}{*}{192} & $\begin{array}{c}0.313 \\
\mathrm{a}\end{array}$ & \multirow{3}{*}{0.012} & \multirow{3}{*}{75} & \multirow{3}{*}{$2 \varnothing 10$} & \multirow{3}{*}{$\begin{array}{c}\text { RECT } \\
\text { ANL }\end{array}$} \\
\hline & B3 & & & & & $\begin{array}{c}0.688 \\
\mathrm{a}\end{array}$ & & & & \\
\hline & B4 & & & & & $1.0 \mathrm{a}$ & & & & \\
\hline \multirow[b]{2}{*}{$\mathrm{C}$} & B5 & \multirow[b]{2}{*}{24} & \multirow[b]{2}{*}{8} & \multirow[b]{2}{*}{3} & \multirow[b]{2}{*}{192} & \multirow[b]{2}{*}{$\begin{array}{c}0.313 \\
\mathrm{a}\end{array}$} & \multirow[b]{2}{*}{0.012} & 50 & \multirow[b]{2}{*}{$2 \varnothing 10$} & \multirow[b]{2}{*}{$\begin{array}{c}\text { RECT } \\
\text { ANL }\end{array}$} \\
\hline & B6 & & & & & & & & & \\
\hline \multirow[t]{2}{*}{$\mathrm{D}$} & B7 & 16 & \multirow[t]{2}{*}{8} & 2 & 128 & $\begin{array}{c}0.263 \\
\mathrm{a}\end{array}$ & \multirow[t]{2}{*}{0.012} & \multirow[t]{2}{*}{75} & \multirow{2}{*}{$2 \varnothing 10$} & \multirow{2}{*}{$\begin{array}{c}\text { RECT } \\
\text { ANL }\end{array}$} \\
\hline & B8 & 32 & & 4 & 256 & $\begin{array}{c}0.363 \\
\mathrm{a}\end{array}$ & & & & \\
\hline \multirow[t]{3}{*}{$E$} & B9 & \multirow{3}{*}{24} & \multirow{3}{*}{8} & \multirow{3}{*}{3} & \multirow{3}{*}{192} & \multirow{3}{*}{$\begin{array}{c}0.313 \\
\mathrm{a}\end{array}$} & 0.00 & \multirow{3}{*}{75} & --- & \multirow{3}{*}{$\begin{array}{c}\text { RECT } \\
\text { ANL }\end{array}$} \\
\hline & B10 & & & & & & 0.008 & & $2 \varnothing 8$ & \\
\hline & B11 & & & & & & 0.017 & & $2 \varnothing 12$ & \\
\hline \multirow[t]{2}{*}{$F$} & B12 & 13.9 & 13.9 & \multirow[t]{2}{*}{1} & \multirow[t]{2}{*}{192} & $\begin{array}{c}0.249 \\
\mathrm{a}\end{array}$ & \multirow[t]{2}{*}{0.012} & \multirow[t]{2}{*}{75} & $2 \varnothing 10$ & $\begin{array}{c}\text { SQUA } \\
\text { RE }\end{array}$ \\
\hline & B13 & 15.6 & 15.6 & & & $0.26 \mathrm{a}$ & & & & $\begin{array}{c}\text { CIRCL } \\
\text { E }\end{array}$ \\
\hline
\end{tabular}

Where:

$1_{\mathrm{o}} \quad$ = length of the opening; $\mathrm{d}_{\mathrm{o}}=$ depth of the opening;

$A_{o}=$ area of the opening; $\quad S_{0}=$ distance from the support to the center of the opening;

$A_{s}{ }^{\prime}=$ steel reinforcement in each side of the opening.

$\mu^{\prime}=$ steel reinforcement ratio in each side of the opening

$a$ = effective shear span; $\mathrm{f}_{\mathrm{cu}}=$ concrete compressive strength (Mpa); 


\section{EFFECT OF OPENINGS ON THE STATICAL BEHAVIOUR}
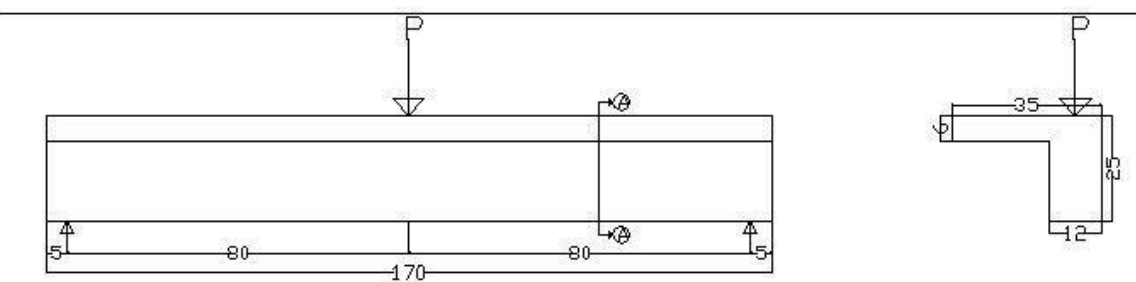

Longi tudinal Elevation

Concrete Dimensions
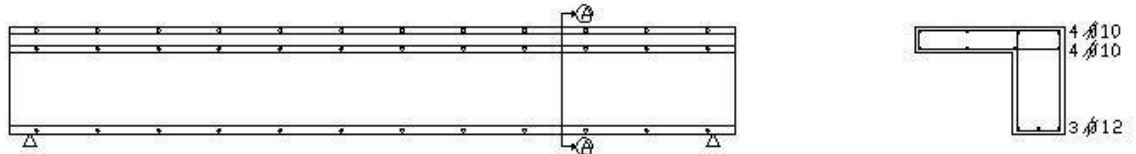

Longl tudinal Relnforcement

Reinforcement Details

Fig. (1):Dimensions and details of beam (B1)

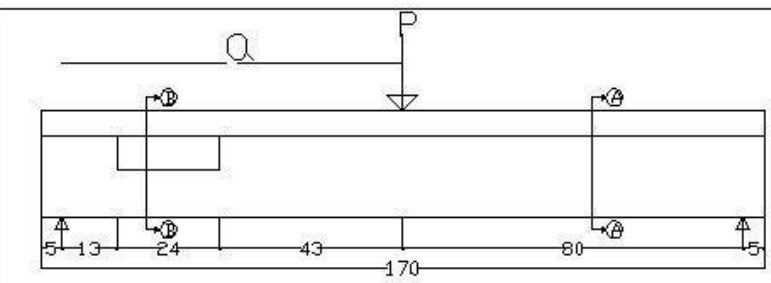

Longi tudinal Elevation

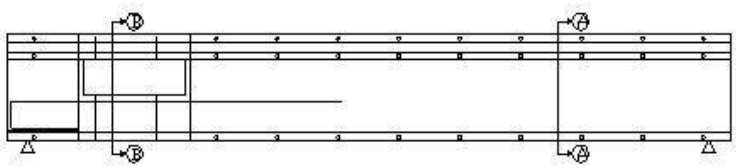

Longitudinal Reinforcement

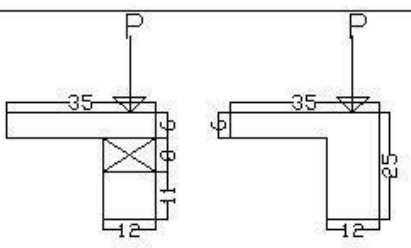

SECTION B-B SECTION A-A

Concrete Dimensions
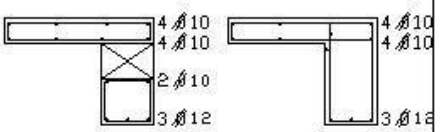

SECTION B-B SECTION A-A

Reinforcement Details

Fig.(2):Dimensions and details of beam (B2) 


\section{Dr. A. Y. ABOUELEZZ, ENG. S.A. EL- BASSUONI}

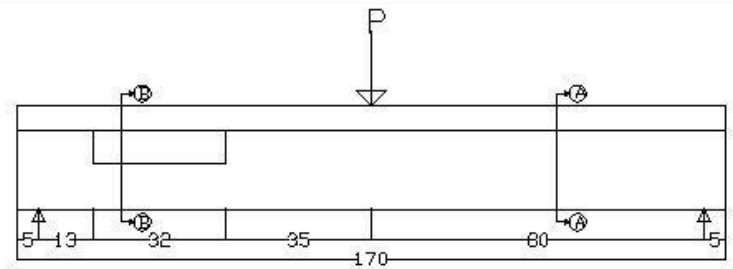

Longitudinal Elevation

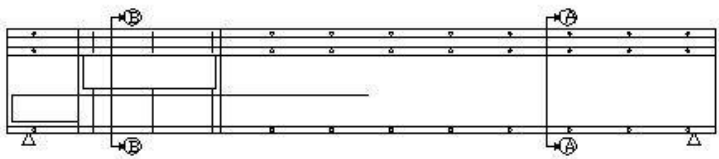

Longitudinal Reinforcement
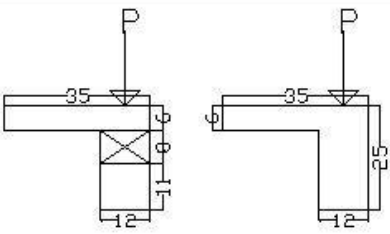

SECTION B-B SECTIUN A-A

Concrete Dimensions
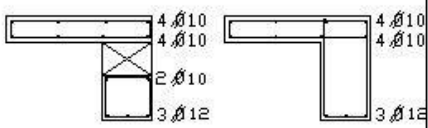

SECTION B-B SECTION A-A

Reinforcement Details

Fig.(3):Dimensions and details of beam (B8)

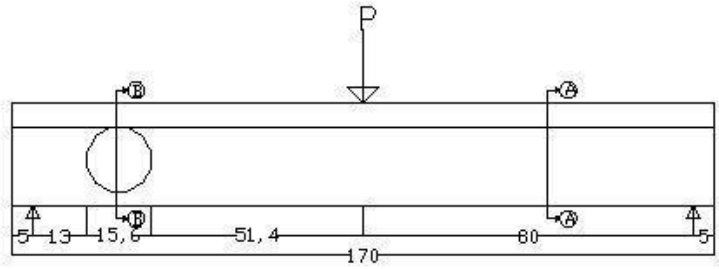

Longitudinal Elevation

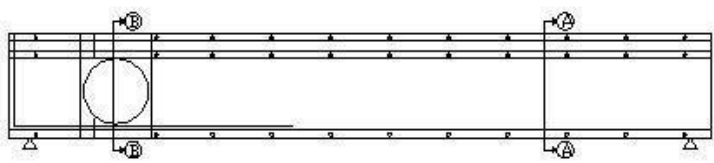

Longi tudinal Reinforcement
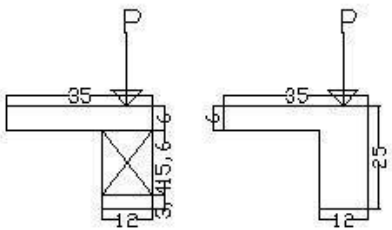

SECTIDN A-A

SECTIDN B-B

Concrete Dimensions
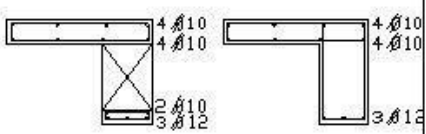

SECTIIN B-B SECTIDN A-A

Reinforcement Details

Fig.(4):Dimensions and details of beam (B13) 


\section{EFFECT OF OPENINGS ON THE STATICAL BEHAVIOUR}

\section{THE CONSTITUENT MATERIALS:}

\section{a) Cement:}

The cement used was Assiut Cement factory which coincided with the requirements of the Egyptian Code ECCS 203

\section{b) Aggregate:}

The used coarse aggregate was basalt supplied from Suez quarries and the used fine aggregate was obtained from Assiut sand quarries

\section{c) Superplastisizer:}

The used superplastisizer was produced by Chemicals for Modern Building (CMB), under the commercial name of (ADDICRETE BVF).

\section{d) Silica Fume:}

It is usually used in amounts about 5 to $10 \%$, by mass, of the total cementitious material.

\section{Mix Proportions:}

The concrete mixes used having a 28 days cubic compressive strength of 50,75 , and $90 \mathrm{Mpa}$. The mix proportions by weight $\left(\mathrm{t} / \mathrm{m}^{3}\right)$ are presented in table $(2)$.

Table (2): Mix Proportion by Weight for The Different Mixes

\begin{tabular}{|c|c|c|c|c|c|c|c|c|c|}
\hline \multirow{3}{*}{$\begin{array}{l}\text { Mix. } \\
\text { No. }\end{array}$} & \multicolumn{8}{|c|}{ Amount of constituent materials $/ \mathrm{m} 3$} & \multirow{3}{*}{$\begin{array}{l}\text { Fc } \\
\text { Mpa }\end{array}$} \\
\hline & \multirow{2}{*}{$\begin{array}{l}\text { Cement } \\
(\mathrm{kg})\end{array}$} & \multirow{2}{*}{$\begin{array}{c}\begin{array}{c}\text { Fine } \\
\text { Aggregate } \\
(\mathrm{Kg})\end{array} \\
\begin{array}{c}\text { Sand } \\
(\mathrm{kg})\end{array}\end{array}$} & \multicolumn{2}{|c|}{$\begin{array}{c}\text { Coarse } \\
\text { Aggregate(kg) }\end{array}$} & \multirow{2}{*}{$\begin{array}{l}\text { Water } \\
\text { (litre) }\end{array}$} & \multirow{2}{*}{$\mathrm{W} / \mathrm{C}$} & \multirow{2}{*}{$\begin{array}{l}\text { Silica } \\
\text { fume } \\
\text { (kg) }\end{array}$} & \multirow{2}{*}{$\begin{array}{l}\text { Super- } \\
\text { plastisizer } \\
(\mathrm{kg})\end{array}$} & \\
\hline & & & $\begin{array}{l}\text { Basalt } \\
\text { No. } 2\end{array}$ & $\begin{array}{l}\text { Basalt } \\
\text { No. } 3\end{array}$ & & & & & \\
\hline 1 & 400 & 620 & 620 & 620 & 162 & 0.4 & 8.64 & 2.4 & 50 \\
\hline 2 & 450 & 610 & 610 & 610 & 157.5 & 0.35 & 40.5 & 9 & 75 \\
\hline 3 & 450 & 628 & 628 & 628 & 135 & 0.3 & 58.5 & 13.5 & 90 \\
\hline
\end{tabular}

A slump test was made for the three previous mixes, and the test results for mixes number 1,2 , and 3 were 40,55 , and $50 \mathrm{~mm}$, respectively. These results agree with the requirements of the Egyptian Code for Design and Construction, (ECCS 203, 2007). 
Dr. A. Y. ABOUELEZZ, ENG. S.A. EL- BASSUONI

Table (3): Results of The Tested Cubes

\begin{tabular}{|c|c|c|}
\hline \multirow{2}{*}{ GROUP NO. } & BEAM NO. & $\begin{array}{c}\text { THE AVERAGE COMPRESSIVE } \\
\text { STRENGTH }\end{array}$ \\
\hline A & B1 & 74.1 \\
\hline \multirow{3}{*}{ B } & B2 & 73.6 \\
\cline { 2 - 3 } & B3 & 75.2 \\
\cline { 2 - 3 } & B4 & 72.9 \\
\hline \multirow{2}{*}{ C } & B5 & 48.8 \\
\cline { 2 - 3 } & B6 & 89.1 \\
\hline \multirow{2}{*}{ D } & B7 & 73.4 \\
\cline { 2 - 3 } & B8 & 76.2 \\
\hline \multirow{3}{*}{ E } & B9 & 74.1 \\
\cline { 2 - 3 } & B10 & 75.6 \\
\cline { 2 - 3 } & B11 & 77.3 \\
\hline \multirow{2}{*}{ F } & B12 & 73.4 \\
\cline { 2 - 3 } & B13 & 75.9 \\
\hline
\end{tabular}

\section{Steel Reinforcement:}

Two types of steel reinforcement were used in fabricating beams for this investigation. Steel of grade 36/52 and 24/35 were was used

\section{Instrumentation and loading system:}

\section{1- Testing Machine:}

The Universal Testing Machine (UMH-100) of capacity 100 ton, with accuracy of $50 \mathrm{Kg}$, was used to test all beams

\section{2- Measuring Devices:}

\section{-Measurement of Beam Deflection:}

Two dial gauges having an accuracy of $(0.002 \mathrm{~mm})$ were used to measure the values of deflection in all beams.

\section{- Measurement of Strain in Reinforcement and Concrete:}

The strains were measured in reinforcement by using electrical strain gauges having gauge length of $20 \mathrm{~mm}$, resistance of $120 \mathrm{Ohm}$, and gauge factor of 2.08. For the concrete, the strain was measured at the top of the vertical side of the beam. It was measured by using electrical strain gauges having gauge length of $60 \mathrm{~mm}$, resistance of $120 \mathrm{Ohm}$, and gauge 
factor of 2.10. The strain gauges were connected to a digital strain indicator (Type P-3500)

\section{Detection of Cracks:}

Cracks were detected through visual observation during testing all beams, as well as marking the propagation of cracks at each load increment. The cracking and ultimate loads were accurately recorded during each test.

\section{TEST RESULTS}

\section{LOAD- DEFLECTION RELATIONSHIPS \\ - LOAD- MID SPAN DEFLECTION DIAGRAMS:}

The measured deflection values were plotted against the corresponding applied loads, from the start of applying the load, and up to failure. The load-deflection curves of the tested beams in all groups are plotted in Figs. (5 to 9).

\section{- LOAD- DEFLECTION AT CENTER}

It was found that the load- center of the opening deflection curves, have the same behavior of the load mid- span deflection curves. As shown in Figs. (10 to 14). The values of maximum deflections at the two positions of mid- span of the beam and center of the opening are summarized in the following table:

Table (4 ): Experimental Test Results of Maximum Deflections , Cracking and Ultimate Loads

\begin{tabular}{|c|c|c|c|c|c|c|c|c|c|}
\hline$G R$ & $\begin{array}{c}B E A \\
M\end{array}$ & $\begin{array}{c}\boldsymbol{\delta} \mathbf{1} \\
(\mathrm{mm})\end{array}$ & $\begin{array}{c}\mathbf{\delta 2} \\
(\mathrm{mm})\end{array}$ & $\begin{array}{l}\delta 2 / \\
\delta 1\end{array}$ & $\begin{array}{c}A V E R A \\
G E \\
V A L U E\end{array}$ & $\begin{array}{c}\mathbf{P}_{\mathbf{c r}} \\
\text { (ton) }\end{array}$ & $\begin{array}{r}\mathbf{P}_{\text {ult }} \\
\text { (ton) }\end{array}$ & $\mathbf{P}_{\mathrm{cr}} / \mathbf{P}_{\mathrm{ult}}$ & $\begin{array}{c}\text { Averag } \\
e \\
\text { Values }\end{array}$ \\
\hline$\underline{A}$ & B1 & 12.60 & 7.80 & 0.619 & 0.619 & 4.0 & 13.1 & 0.305 & 0.305 \\
\hline \multirow{3}{*}{$\underline{\mathbf{B}}$} & B2 & 18.19 & 10.99 & 0.604 & \multirow{12}{*}{0.637} & 2.5 & 9.7 & 0.257 & 0.237 \\
\hline & B3 & 19.33 & 11.83 & 0.612 & & 2.0 & 8.8 & 0.228 & \\
\hline & B4 & 14.91 & 14.91 & 1.000 & & 1.5 & 7.0 & 0.216 & \\
\hline \multirow{2}{*}{$\underline{\mathbf{C}}$} & B5 & 20.48 & 12.22 & 0.597 & & 2.0 & 8.0 & 0.249 & \\
\hline & B6 & 17.52 & 10.57 & 0.603 & & 3.0 & 12.4 & 0.243 & \\
\hline \multirow{2}{*}{$\underline{\mathbf{D}}$} & B7 & 17.20 & 10.37 & 0.603 & & 3.0 & 10.9 & 0.276 & \\
\hline & B8 & 19.76 & 11.74 & 0.594 & & 2.0 & 8.0 & 0.251 & \\
\hline \multirow{3}{*}{$\underline{\mathbf{E}}$} & B9 & 12.12 & 7.83 & 0.646 & & 1.0 & 5.1 & 0.196 & \\
\hline & B10 & 20.80 & 12.32 & 0.593 & & 2.0 & 9.3 & 0.215 & \\
\hline & B11 & 17.85 & 10.61 & 0.594 & & 2.5 & 10.2 & 0.245 & \\
\hline \multirow{2}{*}{$\underline{\mathbf{F}}$} & B12 & 19.16 & 11.38 & 0.594 & & 2.0 & 8.8 & 0.228 & \\
\hline & B13 & 19.83 & 11.97 & 0.604 & & 2.0 & 8.2 & 0.244 & \\
\hline
\end{tabular}




\section{Dr. A. Y. ABOUELEZZ, ENG. S.A. EL- BASSUONI}

Where:

$\delta 1=$ The maximum deflection at the mid- span of the beam $(\mathrm{mm})$;

$\delta 2=$ The maximum deflection at the center of the opening $(\mathrm{mm})$.

$\mathrm{P}_{\mathrm{cr}}=$ experimental cracking load for the tested beams.

$\mathrm{P}_{\mathrm{ult}}=$ experimental ultimate load for the tested beams

From table (4), it can be noted that almost all beams have values of deflections at the centers of the openings equal about 0.6 of the deflection values at the mid span of the beam. 
EFFECT OF OPENINGS ON THE STATICAL BEHAVIOUR ...

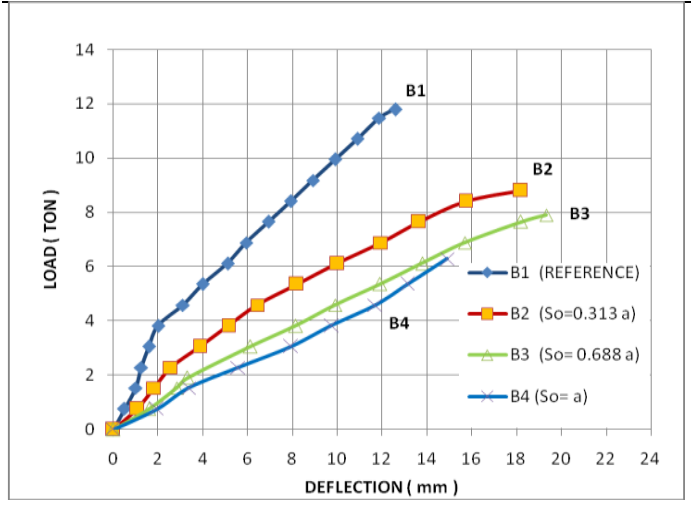

Fig. (5): Relation between the applied load and the measured deflection at the midspan for group (B)

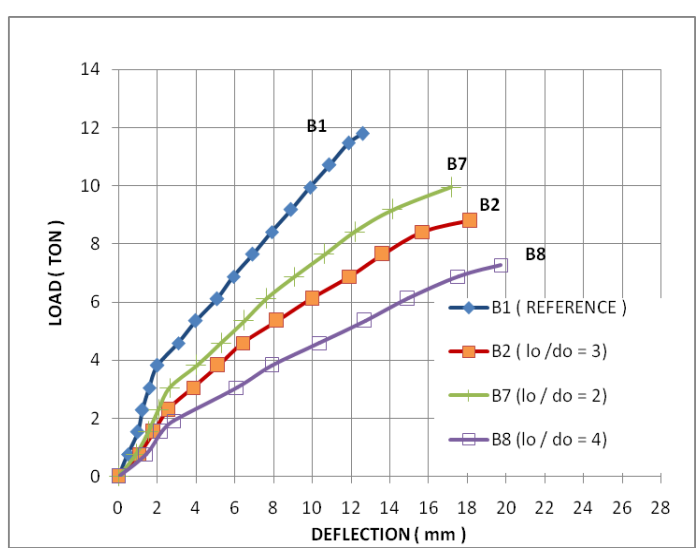

Fig. (6): Relation between the applied load and the measured deflection at the midspan for group (C)

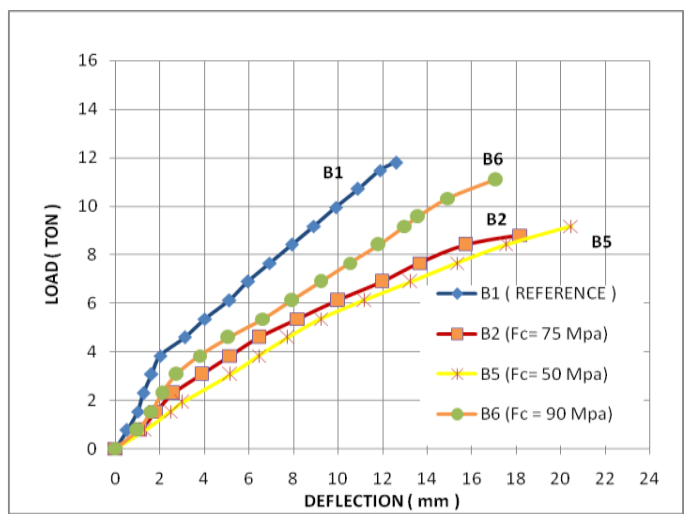

Fig. (7): Relation between the applied load and the measured deflection at the midspan for group (D)

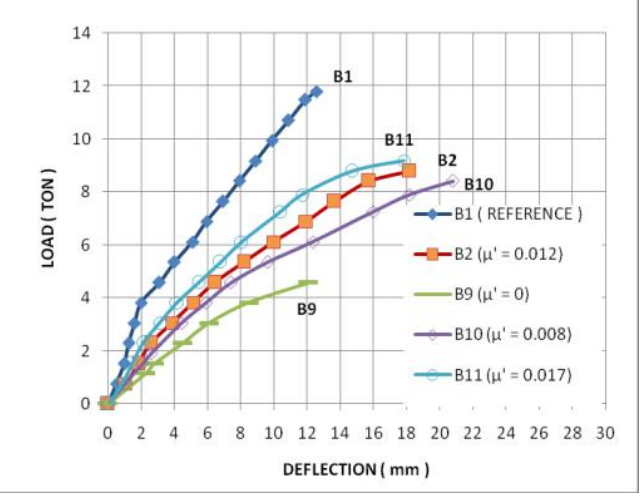

Fig. (8): Relation between the applied load and the measured deflection at the midspan for group $(\mathrm{E})$

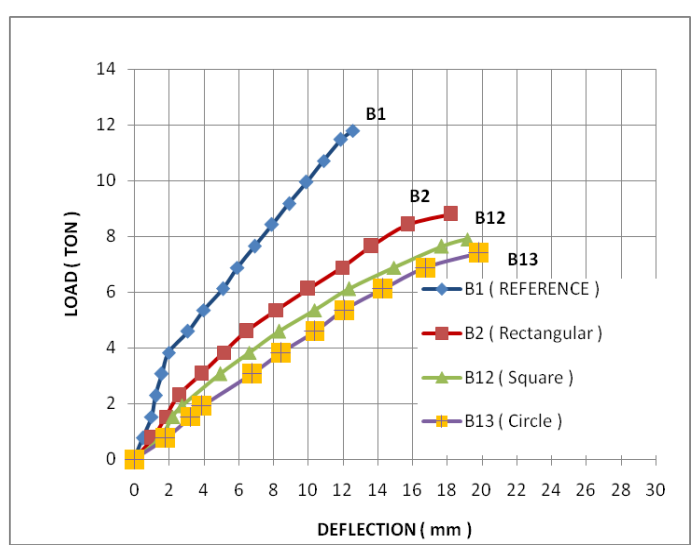

Fig. (9): Relation between the applied load and the measured deflection at the midspan for group $(\mathrm{F})$

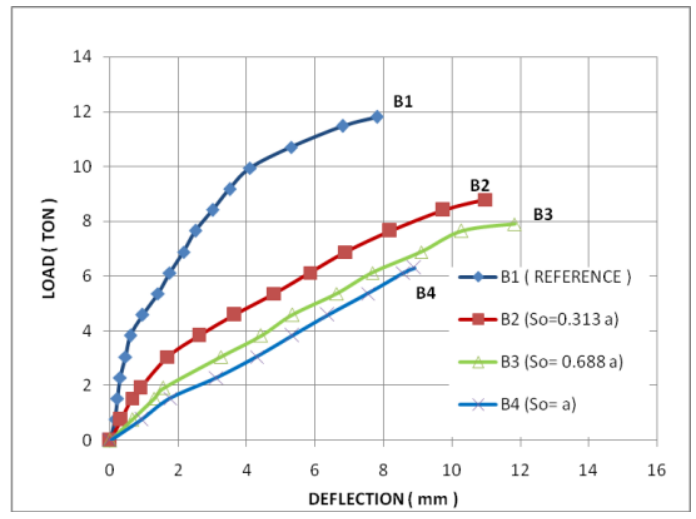

Fig. (10): Relation between the applied load and the measured deflection at the middle of the opening for group (B) 


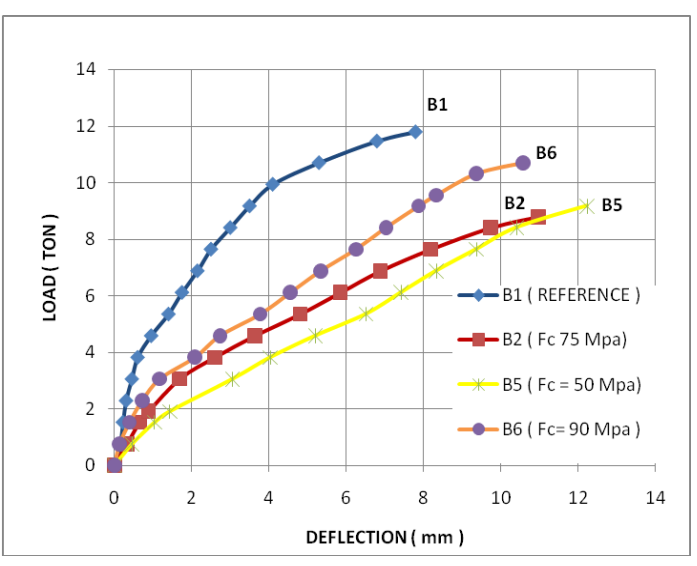

Fig. (11): Relation between the applied load and the measured deflection at the middle of the opening for group (C)

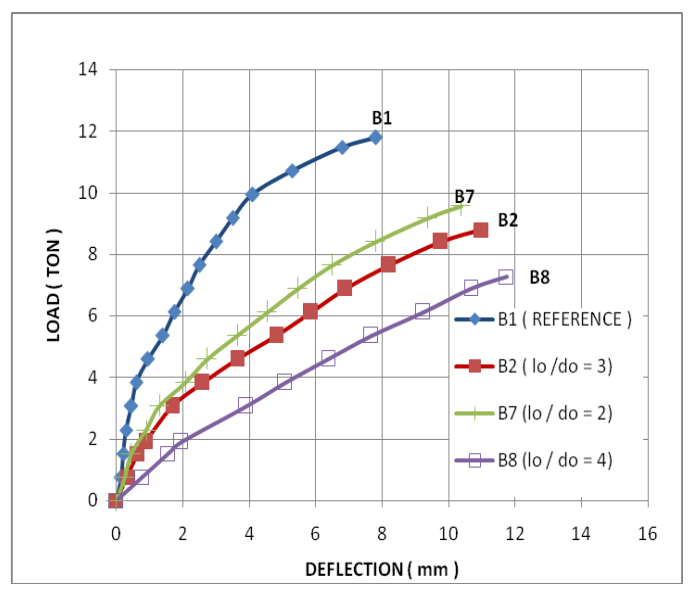

Fig. (12): Relation between the applied load and the measured deflection at the middle of the opening for group (D)

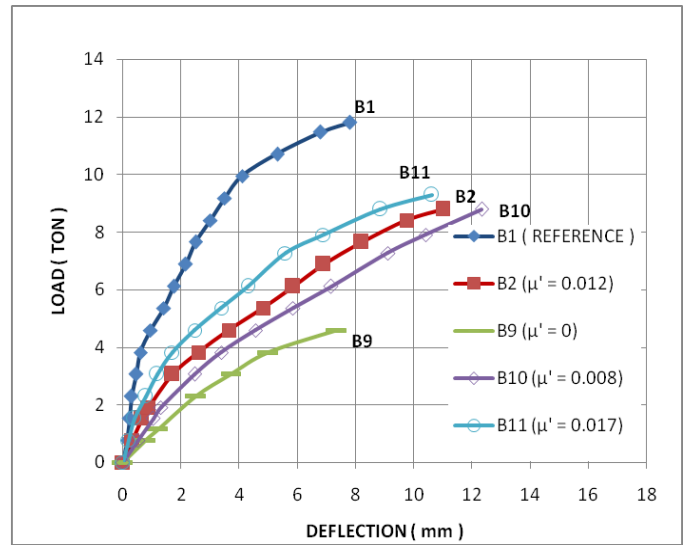

Fig. (13): Relation between the applied load and the measured deflection at the middle of the opening for group (E)

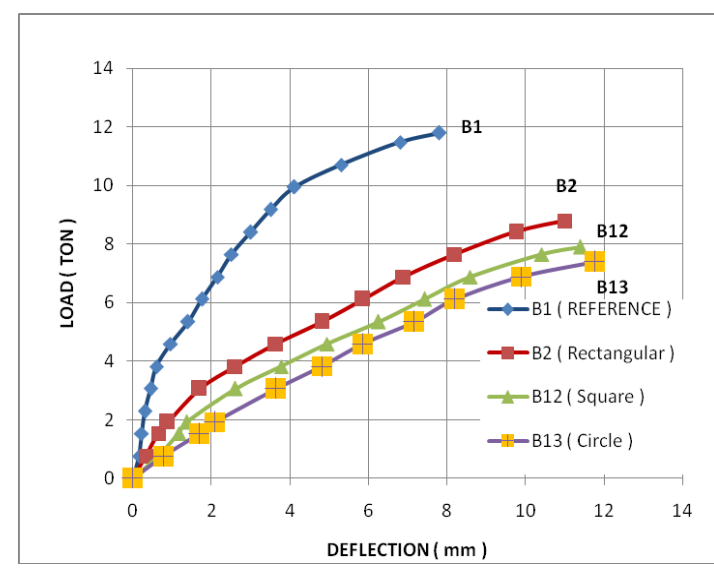

Fig. (14): Relation between the applied load and the measured deflection at the middle of the opening for group $(\mathrm{F})$

\section{CRACKING AND ULTIMATE LOAD:}

While testing the various beams, the first visible cracking load, and the failure load was observed and recorded. It found that craking loads for all beams ranged between $20 \%$ to $30 \%$ of the corresponding values of ultimate load for those beams.

\section{PATTERN OF CRACKS AND MODES OF FAILURE:}

During conducting tests, the load was increased gradually in terms of increments. At each increment of load, the load is maintained constant for a while to draw the cracks on the vertical face of the beams, as well as to record the different measurements of deformations.

Plates (1) to (12) illustrate the pattern of cracks and modes of failure for all the tested beams. The following results and remarks can be detected from these plates.

\section{Control Beam B1 (Group A):}

Plate (1) shows the pattern of cracks for the control beam (B1) without opening. The first visible crack was initiated in the middle of the span, directely under the load, at the bottom surface of the beam, i.e., the crack started in the region of the maximum tensile stress. Then, by increasing the load, the crack grew vertically to a distance more than two- thirds of the total depth of the beam. After continuing in increasing the load, other cracks, beside the main one, occurred and propagated diagonally, making an angle of $50-70^{\circ}$ to the horizontal line. The mode of failure is a typical flexural one, accompanied by crushing of concrete under the point of load application at the top region of the beam. 


\section{Beams of Group (B):}

Beams B2, B3, and B4 show the effect of changing the opening position along the beam horizontal axis on the cracking phenomena.

For beam B2, the ultimate load of 9.7 ton, failure of the beam occurred through the main crack joining the middle of the beam and the point of load application. The final mode of failure was flexural failure type. But for beam B3, at load of 7 ton, failure of this beam happened due to crushing of the concrete at the upper chord of the opening.

\section{Beams of Group (C):}

In this group, the effect of the concrete compressive strength was taken into consideration. Pattern of cracks for beam B5, and B6 are shown in plates (5), and (6), respectively.

For beam B5, and beam B6 at which the concrete compressive strength were 50, and $90 \mathrm{Mpa}$, respectively, the first visible crack was initiated at the middle of the beams in the tension side due to flexural effect. It has been noted that beam B6 (90 Mpa) exhibited more cracks than beam B5 (50 Mpa). However, the width of these cracks was smaller than those of beam B5. By increasing the load, the cracking behavior of those beams was observed to be similar to beam B2. Failure of beams B5, and B6 happened at loads of 8 ton, and 12.4 ton, respectively, due to flexural tension.

\section{Beams of Group (D):}

In this group of beams, the effect of changing the length of the opening on the cracking behavior of beams (B7), and (B8) was considered. Plates (7), and (8) show the pattern of cracks of beams B7, and $\mathrm{B} 8$, respectively.

For beam B7, in which its opening length was $16 \mathrm{~cm}$, the first crack initiated when reaching a load of 3 ton at the bottom fiber of the beam. Increasing the load up to reaching the failure stage (at a load of 10.9 ton), the pattern of cracks and mode of failure were similar to those of beam B2. The difference between the two beams was that the number of cracks at the bottom chord of the opening, and its width were less than those of beam B2 with an opening length equal to $4 \mathrm{~cm}$. That is because decreasing the length of the opening, increases the stiffness of the beam. The failure of this beam happened due to flexural failure.

For beam B8, which had an opening length of $32 \mathrm{~cm}$, the initiation of the first crack happened at the upper corner of the opening, which is closer to the point of load application. With increasing the load, this crack grew in its length and width, accompanied with formation of new flexural and diagonal tension cracks at the bottom surface of the beam, and other cracks underneath the opening. The failure of beam B8 occurred at a load of 8 ton, which may be due to the diagonal tension cracks formed at the region of the opening, and the beam's mode of failure was a diagonal tension one.

\section{Beams of Group (E):}

The pattern of cracks of beams B9, B10, and B11 are shown in plates (9), (10), and (11), respectively. These plates indicated the significant effect of the amount of steel reinforcement located around the opening on the pattern of cracks induced in the beams.

In beam B9, which is made without any steel reinforcement around the opening, the first visible crack initiated at the lowest cracking load for all tested beams $\left(\mathrm{P}_{\mathrm{cr}}=1\right.$ ton), at the bottom chord of the opening, close to the support. With increasing the load, this crack grew in width and length, forming the main crack causing the failure. At the same time, this increase in load, caused the initiation of new cracks at both the opening corners and at the middle of the beam. At a load of 5.1 ton, the failure of the beam happened due to diagonal tension failure at the corner of the opening.

For beams B10, and B11, the pattern of cracks of the two beams was similar to the pattern of cracks of beam B2. For beam B11, cracks around the openings were less than those of beams (B2), and (B10). This is because the increase of horizontal reinforcement around the opening causes the increase of the stiffness of beam chords.

\section{Beams of Group (F):}

In this group of beams, the effect of changing the cross-sectional shape of the opening on the cracking behavior of beams (B12), and (B13) was considered. The pattern of cracks of beams B12 is shown in Plate (12). 


\section{EFFECT OF OPENINGS ON THE STATICAL BEHAVIOUR ...}

For beam B12, the first visible crack is initiated at the lower corner of the opening due to the high induced stresses at the sharp edge corners of the square opening. By increasing the load, this crack increased in its length and width. Also new cracks were initiated at the opening corners and at the middle of the beam. The final mode of failure of this beam was a diagonal tension one.

For beam B13, the first visible crack is initiated at the middle part of the opening despite its circular shape, that is due to the relatively big depth of beam B13. By increasing the load, the cracking behavior becomes similar to the one that happened in beam (B12), and exhibiting the same mode of failure.

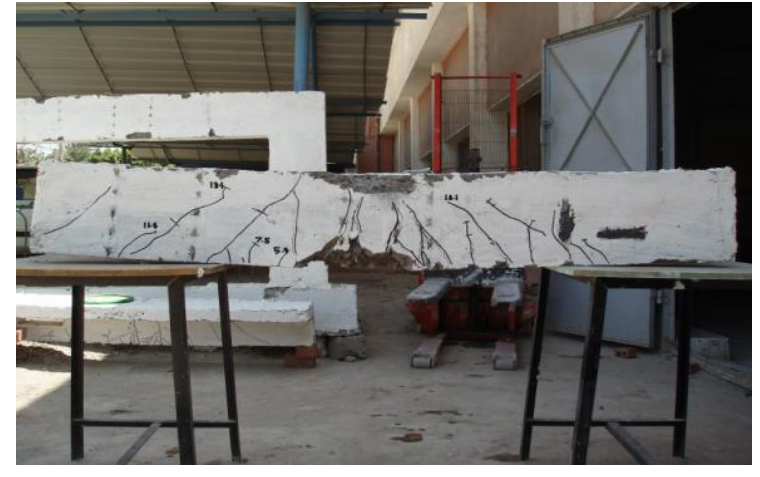

Plate (1): The pattern of cracks and mode of failure of beam (B1)

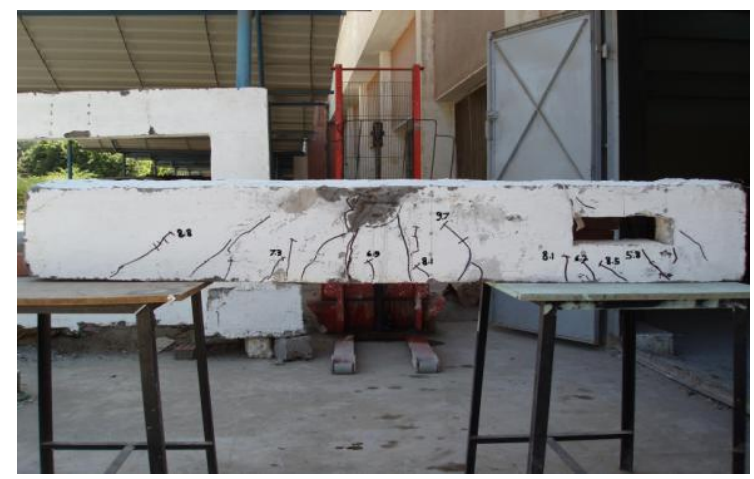

Plate (2): The pattern of cracks and mode of failure of beam (B2)

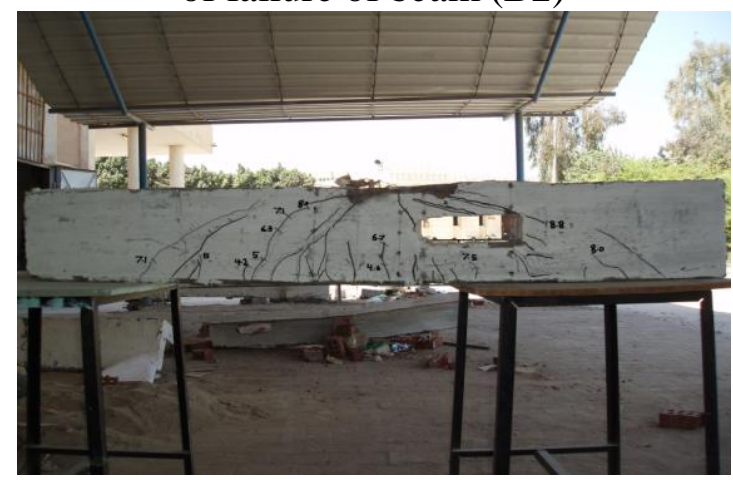

Plate (3): The pattern of cracks and mode of failure of beam (B3)

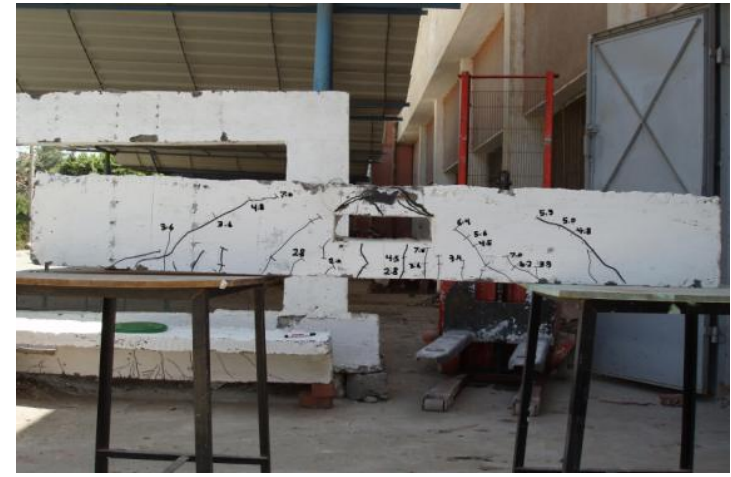

Plate (4): The pattern of cracks and mode of failure of beam (B4)

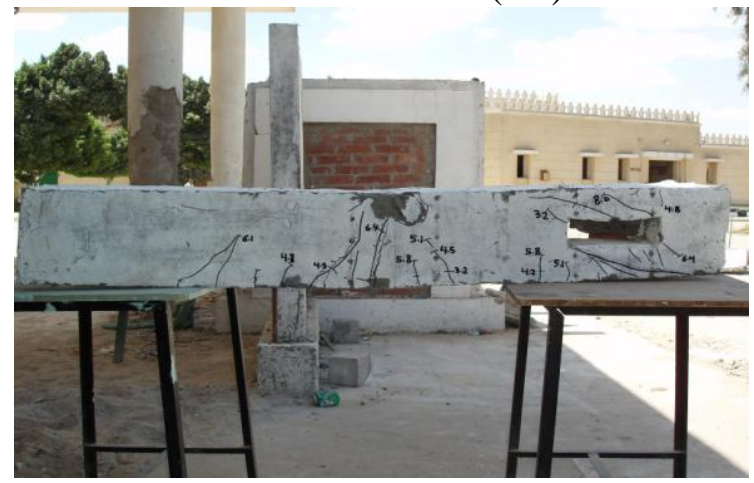

Plate (5): The pattern of cracks and mode of failure of beam (B5)

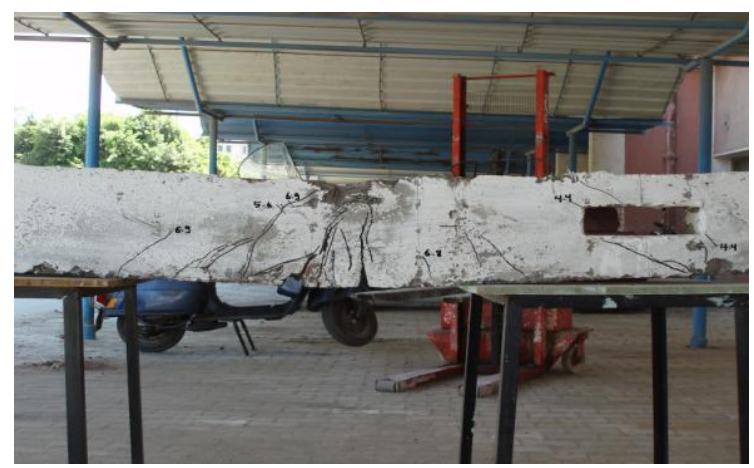

Plate (6): The pattern of cracks and mode of failure of beam (B6) 


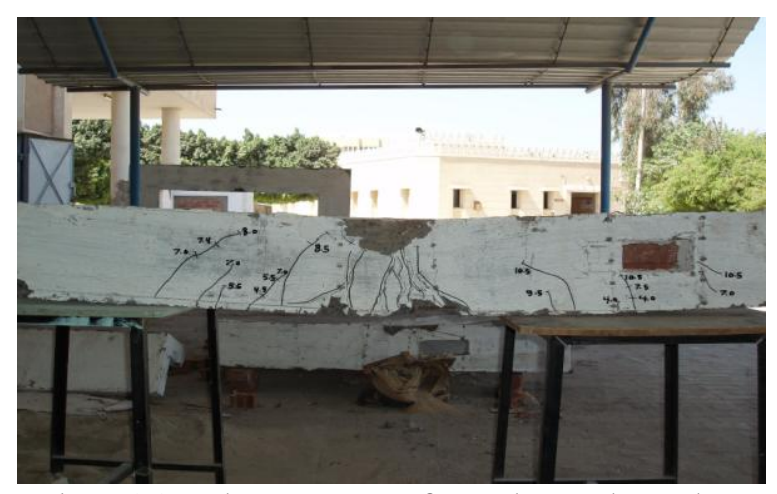

Plate (7): The pattern of cracks and mode of failure of beam (B7)

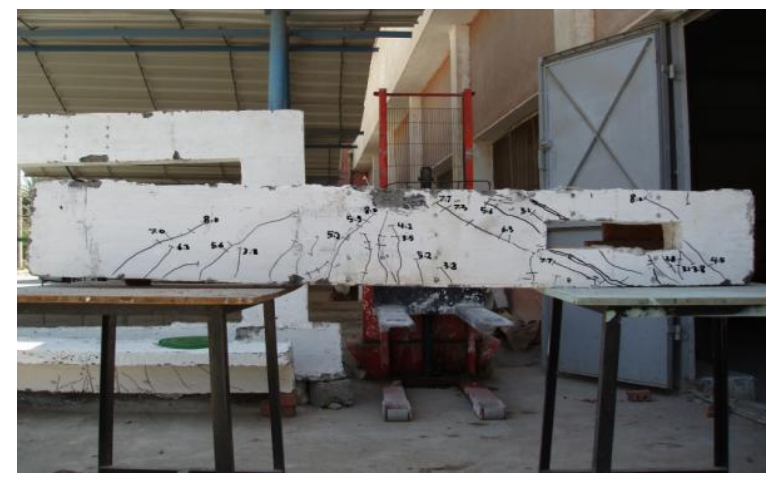

Plate (8): The pattern of cracks and mode of failure of beam (B8)

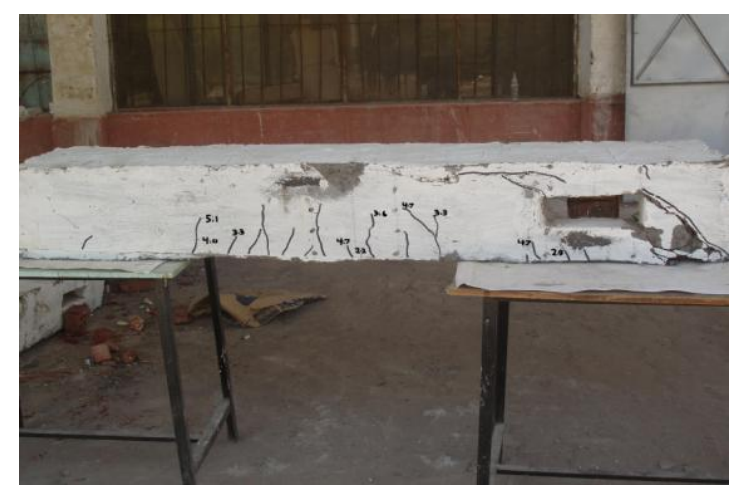

Plate (9): The pattern of cracks and mode of failure of beam (B9)

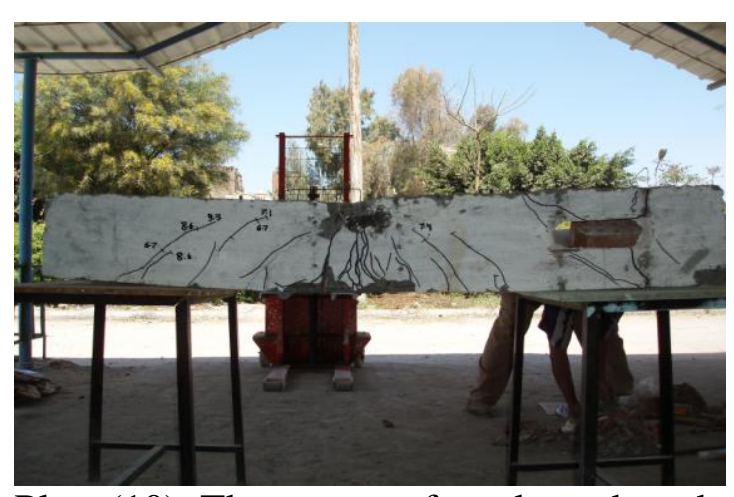

Plate (10): The pattern of cracks and mode of failure of beam (B10)

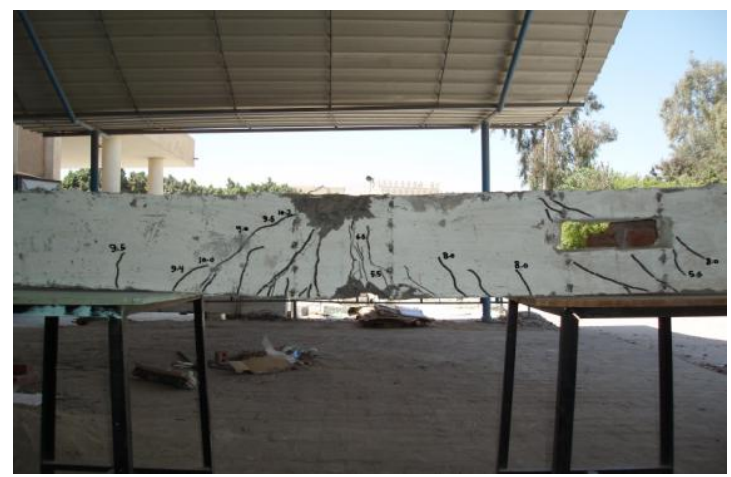

Plate (11): The pattern of cracks and mode of failure of beam (B11)

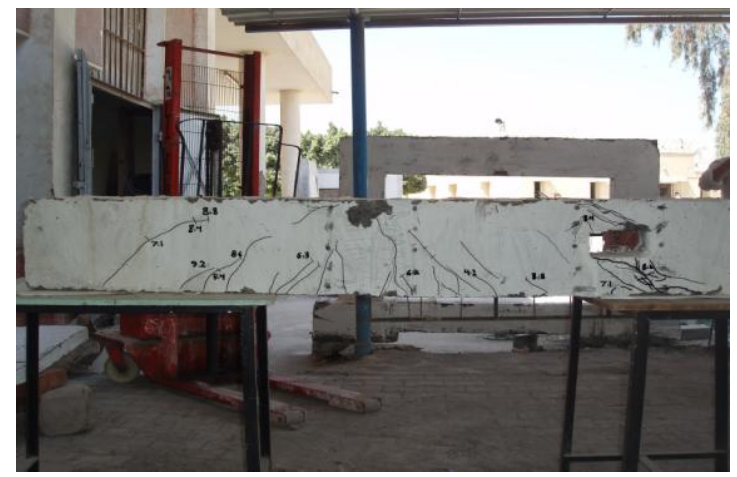

Plate (12): The pattern of cracks and mode of failure of beam (B12)

\section{LOAD- STRAIN RELATIONSHIPS}

The straining actions in the forms of strain measurements were determined in both steel reinforcement and concrete.

The steel- strains were measured at three critical positions by using electrical resistance strain gauges. Strain gauges were fixed at the lower tension steel reinforcement of the beam, and at the steel bars around the opening, (horizontal, and vertical

\section{Group (B):}

As the distance between the nearest support to the center of the opening increase, the strain values in the main steel of the beam increase too. Increasing the distance between the center of the opening to the nearest support, the maximum induced strains in the lower steel reinforcement increase. It has been noticed that the strain values in the steel reinforcement around the opening increase with increasing the distance between the center of the opening to the nearest support. 


\section{Group (C):}

By increasing the compressive strength of the used concrete, the strains in both the steel reinforcement either in the main steel or at the reinforcement around the opening and concrete decrease. Also increasing the concrete compressive strength, the induced strains in the main steel reinforcement decrease. Thr strain values in the steel reinforcement around the opening increase by decreasing the concrete compressive strength.

\section{Group (D):}

It can be noticed from the study that the values of strains are getting higher, by increasing the length of the opening.

\section{CONCLUSIONS:}

Thirteen high strength reinforced concrete L- shaped beams, having openings in their webs were tested under static loading to investigate the effect of these openings on the behavior of these beams. The study includes the effect of different parameters like: opening position, grade of used concrete, opening length, amount of steel reinforcement around the opening, and shape of the opening. From the test results of the experimental part, and the discussion of these results, it was generally concluded that openings have a significant effect on both the deformation and load characteristics of the L- beams. The following conclusions and recommendations can be extracted:

1. Increasing the distance between the center of the opening to the nearest support, decreases both the cracking and ultimate loads. Also, causes an increase in the values of the deflection at the midspan of the beam, as well as the values of the deflection at the center of the opening. A premature failure occurred at an early stage of loading when fixing the opening directly under the point of loading application.

2. At early stages of loading the relation between the strains and load is linear. Meanwhile, at the ultimate stages of loading, it was observed that, the stress distribution is non- linear depending on the distribution of cracks at the hole boundary, but far from the opening zone, the stress distribution across the depth of the beam follows a relatively linear relation.

3. Increasing the concrete compressive strength improves cracking and ultimate loads, Also, with compressive strength equals $90 \mathrm{Mpa}$ produced approximately the same ultimate load as the control beam without openings, made of concrete with compressive strength equals $75 \mathrm{Mpa}$. Increasing the concrete compressive strength has also decreased both the deflection and maximum induced strains

4. Increasing the ratio between the opening length to the opening depth (lo/do), decreased both the cracking and ultimate loads. Also increasing the opening length, increases the number and width of cracks

5. With increasing in the opening length, it was noticed that both the maximum deflections at the midspan of the beam and at the center of the opening are increased. And The values of the measured strains, either in main steel or around the opening, have increased as the length of the opening increased.

6. Increasing the amount of steel reinforcement around the openings in the tested beams improve. the general behavior of these beams as indicated in the following conclusions:

7. Increasing the steel reinforcement ratio around the opening causes an improvement in the stiffness of the opening region, and consequently, both the cracking and

8. Changing the shape of the opening affects the values of both the cracking and ultimate loads. The rectangular shape of the opening, which has the lowest depth, produces the highest values of both cracking and ultimate loads, The lowest values of strains were recorded with the rectangular opening, and the circular opening has a smooth perimeter, which is attributed to the effect of the height of the opening.

\section{RECOMMENDATIONS FOR THE FUTURE WORK}

A future work is recommended to throw the light on the behavior of high strength reinforced concrete L- shaped beams under the following effects:

1- Theoretical analysis by using finite element program, to compare the theoretical results with the experimental ones. 
2- The effect of applying repeated loading technique upon the behavior of high- strength reinforced concrete L- beams with web openings.

The effect of strengthening the web openings with carbon fiber reinforced plastic laminates.

\section{REFERENCES}

"(ACI 318-02) Building Code Requirements for Structural Concrete, and Commentary (ACI 318R02),"2002.

Abd El- Shafy, Z. E., "Static Behaviour of High Strength Reinforced Concrete T- Beams with Large Web Opening in Negative Moment, Ph. D. Thesis, Assiut University, Egypt, 2007

Nassef, M. B.; Ibrahim, S.; and El-Ghazouly, "Behavior of Reinforced Concrete Beams with Openings in Shear Zone", ESEC Proceedings, V. 3, Cairo University, Egypt, 1985.

Mansur, M. A., "Design of R.C. Beams with Transverse Openings", web search; cvemansu@nus.edu.sg., 2004

Tan, K. H.; Mansur, M. A.; and Huang, L. M., "Reinforced Concrete T- Beams with Large Web Openings in Positive and Negative Moment Regions", ACI Structural Journal, pp. 277- 284, May / June 1996.

\section{تأثير الفتحات على السلوك الإستاتيكى للكمرات الخرسانية المسلحة

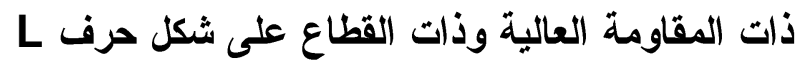

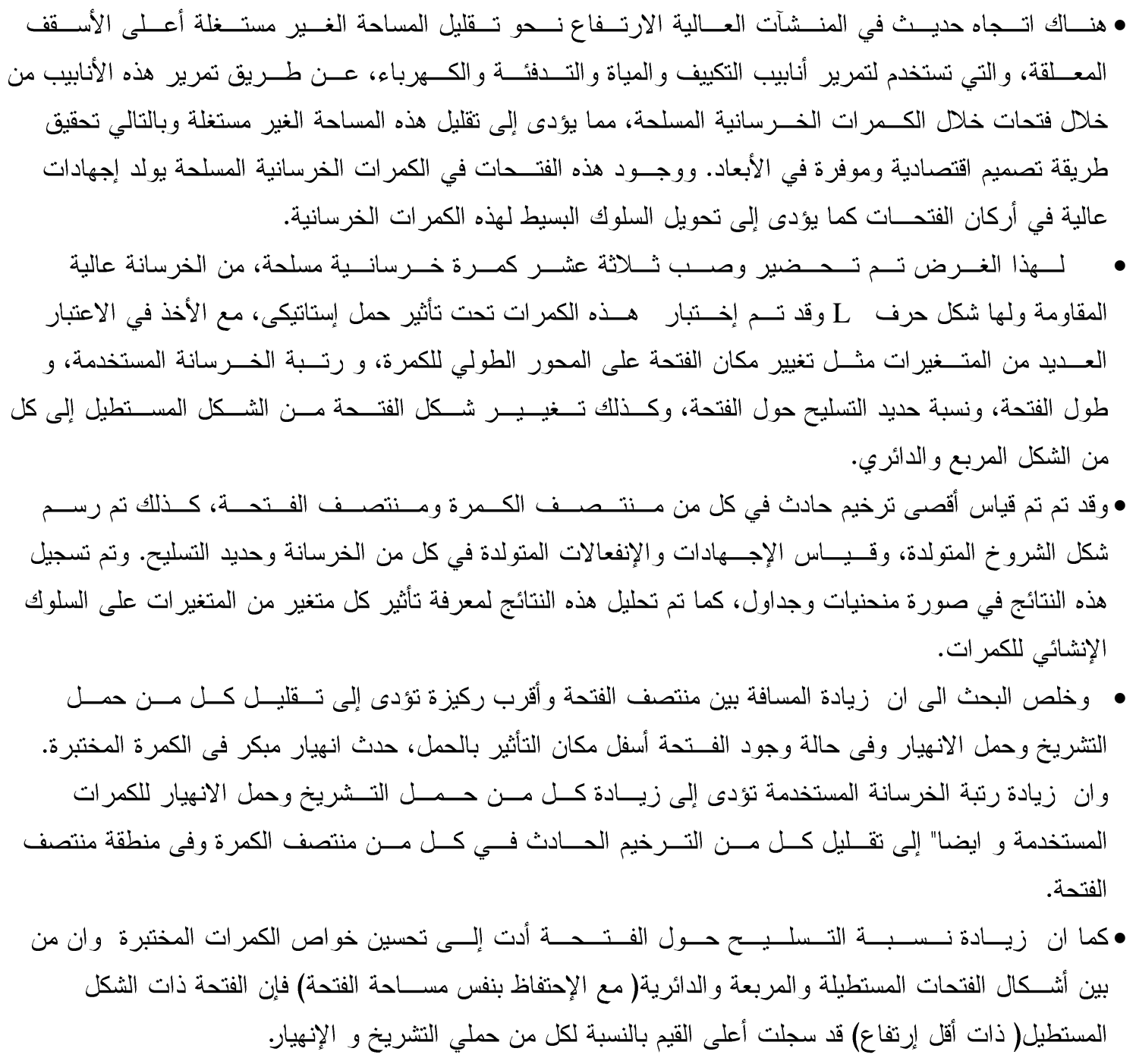

